\title{
Acupuncture and electroacupuncture in the treatment of carpal tunnel syndrome: Systematic review
}

\author{
Marc Badia $^{1} \quad$ Manel M. Santafé ${ }^{1}$ \\ ${ }^{1}$ Unit of Histology and Neurobiology, Department of Basic Medical \\ Sciences, Faculty of Medicine and Health Sciences, Universitat Rovira \\ i Virgili, Reus, Spain \\ Rev Fisioter Invasiva 2020;3:13-25.
}

\begin{abstract}
Address for correspondence Manel M. Santafé, MD, PhD, Unidad de Histología y Neurobiología, Departamento de Ciencias Médicas Básicas, Facultad de Medicina y Ciencias de la Salud, Universitat Rovira i Virgili, Carrer de St Llorenç, 21, 43201, Reus, Tarragona, Spain (e-mail: manuel.santafe@urv.es).
\end{abstract}

\begin{abstract}
Keywords

- magnetic resonance

- median nerve

- neurography

- neuronal plasticity

- pain

Introduction Carpal tunnel syndrome (CTS) is the most diagnosed compression neuropathy of the upper limb. In mild and moderate cases, the treatment is extensive and controversial, whereas severe cases receive surgical intervention.

Objective To analyze the scientific evidence on the effectiveness of treatment of CTS using acupuncture and electroacupuncture.

Methods The PRISMA declaration was followed. A literature search was performed using the following databases: Clinical Evidence BM], NICE, Cochrane Library, PubMed, PEDro, Science Direct, SciELO, Google Scholar. The search strategy used the terms "acupuncture", "electroacupuncture" "carpal tunnel syndrome". The inclusion criteria limited studies to English publications. The risk of bias was assessed for each study using the Cochrane scale. The level of evidence and the level of recommendation was determined using the SIGN scale. Results The search retrieved 698 articles in total. After applying the inclusion and exclusion criteria, 21 articles were included. The level of evidence of all the articles was medium-high. The level of recommendation was medium, and the risk of bias was neutral, with a tendency towards low bias. The articles included revealed symptomatic and neurophysiological improvements, both peripheral as well as central, due to the cerebral response that occurs associated with the function of the median nerve.

Conclusion Acupuncture and electroacupuncture are a therapeutic option for mild to moderate CTS with a medium level of scientific evidence, tending towards a high level, and with a medium level of recommendation.
\end{abstract}

\section{Introduction}

Carpal tunnel syndrome (CTS) is a neuropathy caused by the compression and traction of the median nerve in the carpal tunnel, delimited by the carpal bones and the transverse carpal ligament. ${ }^{1}$ The clinical symptoms of CTS are syndromic, including paresthesia and nocturnal pain, normally related with poor positioning of the radius. ${ }^{2}$ This syndrome is very common ( $4-5 \%$ of the general population), especially in people between $40-60$ years old. Furthermore, it is more frequent in women $(9.2 \%)$ than in men $(6 \%)^{2-4}$

received

November 1, 2019

accepted

November 22, 2019
DOI https://doi.org/

10.1055/s-0040-1701432. ISSN 2386-4591.
The carpal tunnel is an osteofibrous outlet between the flexor retinaculum and the carpal bones. The roof of this tunnel is the fibrose carpal ligament, located deep in the intermediate region of the flexor retinaculum. In this space, nine tendons are found with their sheath and the median nerve. The nerve enters the tunnel in the midline or slightly radial to the same. ${ }^{5}$ The median nerve has sensory branches to supply the three radial digits and the radial half of the fourth finger, as well as the palmar cutaneous sensory branches, which innervate the skin of the palm, ${ }^{6}$ and the recurrent thenar branch. The sensitive area of the median
Copyright @ 2020 by Thieme Revinter Publicações Ltda, Rio de Janeiro, Brazil
License terms

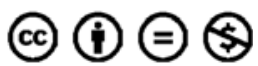


nerve comprises the palmar aspect of the three radial fingers, and the radial half of the fourth finger, the dorsal aspect of the last two phalanges of the three first fingers, and the external half of the fourth finger. The motor branch passes by the distal aspect of the ligament, although in $20 \%$ of cases it is transligamentary, and because of this anatomic variant, an isolated compression exits at the level of the ligamentous outlet. The motor branch innervates the abductor pollicis brevis and the first lumbrical muscles.

Anatomically, two points of compression exist for the median nerve, one at the proximal border of the carpal tunnel, caused by wrist flexion and due to the change of thickness and stiffness between the forearm fascia and the proximal portion of the flexor retinaculum, and a second in the narrowest portion of the tunnel, at the level of the hook of the hamate. Pathological changes are thought to occur in the ligaments that surround the nerves, including alterations in the quantity and flexibility of the connective tissue as the source of the increase in pressure. This increase in pressure of the carpal tunnel causes the ischemic compression of the median nerve. ${ }^{7}$ In CTS, the nocturnal increase in pressure at the level of the tunnel may be due to several factors, such as the redistribution of fluids of the upper limbs in supine position, the lack of muscle pumping mechanisms which contribute towards draining the interstitial liquid in the carpal tunnel, the tendency to place the wrist in flexion, increasing pressure within the canal, an increased blood pressure during the second half of the night, and a drop in the level of cortisol. ${ }^{8}$

Median nerve entrapment can cause disorders of intraneural microcirculation, and injuries to the myelin sheath and the axon (altered function and dysfunction or damage from the point of compression in the distal direction). ${ }^{6}$ Additionally, there may be decomposition of the hematoencephalic barrier of the median nerve, formed by perineural cells and endothelial cells of endoneural capillaries. ${ }^{5}$ Together, these events can provoke an increased pressure of the endoneural liquid and the development of an intrafascicular edema, ${ }^{9}$ provoking an early impairment of the perineural and endoneural microcirculation, with fibrosis and secondary axonal demyelination. Demyelination is responsible for blocking the nerve transmission (neuropraxia) recorded under electromyography, and, if the compression persists, it can lead to Wallerian degeneration. ${ }^{1}$ The rapid development of edema with epineural predominance leads to the inflammation of the nerve, limiting its ability to slide during movements. In response to this injury, there is an increased density of fibroblasts, of the size of the collagen fibers, an increase of type-III collagen, and vascular proliferation in the subsynovial connective tissue. ${ }^{10}$ This scar tissue is formed around the median nerve, ${ }^{11}$ which, in turn, contributes to the nerve entrapment.

Treatment of CTS may be conservative or surgical. Conservative treatment may be active or passive. Passive treatments are based on the use of a wrist splint and infiltration of corticosteroids. Immobilization of the wrist in a neutral position of $0^{\circ}$ of extension can provide symptom relief. ${ }^{12}$ Furthermore, infiltration with corticosteroids is indicated in patients with mild to moderate clinical symptoms, offering a marked relief mainly for pain. ${ }^{13,14}$ Active treatments are applied to patients with mild and moderate symptoms, and they include physical therapy, thermotherapy, electrotherapy, ultrasound therapy, laser, magnetotherapy, and manual techniques of mobilization of the carpal bones.

Acupuncture is reported to modulate the immune response and decrease inflammatory mediators (IL1,2 and FNT) which induce inducible cyclooxygenase (COX2). $\mathrm{COX} 2$ has an antiinflammatory effect as it decreases the synthesis of prostaglandins. ${ }^{15}$ Furthermore, endogenous opioid activation has been suggested. ${ }^{16}$ In addition, electroacupuncture can develop a powerful inhibitory effect upon hyperalgesia in the short term, as well as an anti-inflammatory effect. It appears that the effects of electroacupuncture on hyperalgesia and inflammation can involve both the endocrine system and the nervous system. ${ }^{17,18}$ From the endocrine point of view, the participation of the suprarenal system has been suggested, therefore, producing an anti-inflammatory effect. ${ }^{19,20}$ In addition, at the spinal level, electroacupuncture inhibits the expression of Fos (transcription factor) ${ }^{19,20}$ as well as inducing an increased expression of opioid receptors mu and delta. ${ }^{21,22}$

In the treatment of CTS, acupuncture is an easily accessed resource, with a low cost and without secondary effects, especially compared to more conventional treatments, such as infiltration of corticosteroids or surgical intervention. Thus, the aim of this systematic review was to evaluate the published evidence on the use of acupuncture for the treatment of CTS, and to assess the effectiveness of this treatment approach to therefore validate its use.

\section{Methods}

This systematic review has followed the criteria of the PRISMA declaration.

Selection criteria. The search was limited to:

- Case series, case studies, clinical trials, case-control studies, randomized controlled trials.

- Publications in English.

- Subjects with a medical diagnosis of carpal tunnel syndrome.

- Studies in which the intervention/therapy is acupuncture in carpal tunnel syndrome.

Studies which did not fulfill the previously described requisites were excluded, together with systematic reviews, as the aims of these were different to that of the present review.

Search strategy. A literature search was performed in the following databases: Cochrane Library, PubMed, Clinical Evidence BMJ, NICE, PEDro, Science Direct, SciELO, and Google Scholar. The last search was performed on April 21, 2019.

The search strategy used was based on the terms "acupuncture" and "electroacupuncture" and "carpal tunnel syndrome" as the key word related to CTS, to locate articles within the objectives of the review. Subsequently, the articles were selected according to eligibility criteria. Finally, systematic reviews were excluded. In all of the databases, the following terms were used: (acupuncture[MeSH Terms] OR 
acupuncture[All Fields] OR acupuncture therapy[MeSH Terms] OR (acupuncture[All Fields] AND therapy[All Fields]) OR acupuncture therapy[All Fields]) AND (carpal tunnel syndrome[MeSH Terms] OR (carpal[All Fields] AND tunnel [All Fields] AND syndrome[All Fields]) OR carpal tunnel syndrome[All Fields]) AND (electroacupuncture[MeSH Terms] OR electroacupuncture[All Fields]) AND (carpal tunnel syndrome[MeSH Terms] OR (carpal[All Fields] AND tunnel [All Fields] AND syndrome[All Fields]) OR carpal tunnel syndrome[All Fields]).

Study selection. After performing the database search and downloading the total results, firstly, the title and abstract of all articles were read to exclude the articles which failed to fulfill the previously described eligibility criteria. Thereafter, records which were duplicated among the different databases were removed. The resulting articles were then read in-depth, to determine whether they fulfilled the eligibility criteria and to further screen those to be used for the data analysis. Subsequently, the selected studies were analytically read for data collection. A results table was created to determine the inclusion and exclusion criteria according to the specified eligibility criteria.

Risk of bias of individual studies. - Table 1 displays the risk of bias of each study, using the bias risk scale by Cochrane.
Level of evidence and degree of recommendation. The level of evidence and the degree of recommendation of each individual study is shown in - Table $\mathbf{2}$, based on the scale proposed by the Scottish Intercollegiate Guidelines Network (SIGN).

Synthesis of the results. To unify the results of the selected studies for the performance of the systematic review, a table was created, (-Table 3 ) featuring the study results, based on eight items: author and year, design, subjects and stage of illness, intervention, duration or follow-up, outcome measures, relevant findings, conclusions or commentaries. The results were then analyzed and interpreted as presented in the discussion.

\section{Results}

The aim of this review was to demonstrate the scientific evidence of the effects of acupuncture and electroacupuncture on the evolution and treatment of CTS.

Eight databases were consulted in this review, retrieving 698 articles, of which 20 were from the Clinical Evidence BMJ search engine, 45 were from NICE, 3 were retrieved from the Cochrane Library, 59 were from PubMed, 25 were from PEDro, 437 were from Science Direct, 1 was from SciELO, and, 108 were retrieved from Google Scholar.

Table 1 Evaluation of risk of bias of individual studies. Analysis of risk of bias of the studies included, using the COCHRANE tool

\begin{tabular}{|c|c|c|c|c|c|c|c|}
\hline Article & Item 1 & Item 2 & Item 3 & Item 4 & Item 5 & Item 6 & Item 7 \\
\hline Schulman et al, $2008^{23}$ & $(-)$ & $(-)$ & $(-)$ & $(-)$ & $(-)$ & $(+)$ & $(-)$ \\
\hline Shokunbi, $2014^{24}$ & $(-)$ & $(-)$ & $(-)$ & $(-)$ & $(-)$ & $(-)$ & $(-)$ \\
\hline Napadow et al, $2004^{25}$ & $(-)$ & $(-)$ & $(-)$ & $(+)$ & $(+)$ & $(+)$ & $(+)$ \\
\hline Zailaa, $2010^{26}$ & $(+)$ & $(+)$ & $(-)$ & $(+)$ & $(+)$ & $(+)$ & $(+)$ \\
\hline Ding and Shen, $2013^{27}$ & $(+)$ & $(+)$ & $(-)$ & $(-)$ & $(+)$ & $(+)$ & $(-)$ \\
\hline Wong et al, $2016^{28}$ & $(+)$ & $(+)$ & $(-)$ & $(-)$ & $(+)$ & $(+)$ & $(-)$ \\
\hline Dimitrova et al, $2019^{29}$ & $(+)$ & $(+)$ & $(-)$ & $(+)$ & $(+)$ & $(+)$ & $(-)$ \\
\hline Chen et al, $2017^{30}$ & $(+)$ & $(+)$ & $(-)$ & $(-)$ & $(+)$ & $(+)$ & $(-)$ \\
\hline Ural and Öztürk, $2017^{31}$ & $(+)$ & $(+)$ & $(-)$ & $(-)$ & $(+)$ & $(+)$ & $(-)$ \\
\hline Maeda et al, 2017. ${ }^{32}$ & $(-)$ & $(-)$ & $(-)$ & $(+)$ & $(+)$ & $(+)$ & $(+)$ \\
\hline Hadianfard et al, $2015^{33}$ & $(+)$ & $(+)$ & $(-)$ & $(-)$ & $(+)$ & $(+)$ & $(-)$ \\
\hline Maeda et al, 2013a $a^{34}$ & $(+)$ & $(+)$ & $(-)$ & $(+)$ & $(-)$ & $(+)$ & $(-)$ \\
\hline Ho et al, $2014^{35}$ & $(-)$ & $(-)$ & $(-)$ & $(+)$ & $(+)$ & $(+)$ & $(-)$ \\
\hline Maeda et al, $2013 b^{36}$ & $(+)$ & $(+)$ & $(-)$ & $(-)$ & $(+)$ & $(+)$ & $(-)$ \\
\hline Khosrawi et al, $2012^{37}$ & $(+)$ & $(+)$ & $(-)$ & $(-)$ & $(-)$ & $(+)$ & $(+)$ \\
\hline Kumnerddee and Kaewtong, $2010^{38}$ & $(+)$ & $(+)$ & $(-)$ & $(-)$ & $(+)$ & $(+)$ & $(+)$ \\
\hline Yang et al, $2011^{39}$ & $(+)$ & $(+)$ & $(-)$ & $(-)$ & $(-)$ & $(+)$ & $(-)$ \\
\hline Yang et al, $2009^{40}$ & $(+)$ & $(+)$ & $(-)$ & $(-)$ & $(-)$ & $(+)$ & $(-)$ \\
\hline Napadow et al, $2007 a^{41}$ & $(+)$ & $(+)$ & $(+)$ & $(-)$ & $(+)$ & $(+)$ & $(-)$ \\
\hline Napadow et al., 2007b ${ }^{42}$ & $(+)$ & $(+)$ & $(+)$ & $(-)$ & $(+)$ & $(+)$ & $(-)$ \\
\hline Yao et al, $2012^{43}$ & $(+)$ & $(+)$ & $(-)$ & $(+)$ & $(+)$ & $(-)$ & $(-)$ \\
\hline
\end{tabular}

Notes: (+), low bias; (-), high bias. Item 1: generation of the random sequence. Item 2: concealed allocation. Item 3: type of blinding of participants and researchers. Item 4: type of blinding of evaluators. Item 5: follow-up and conclusions. Item 6: selective report of results. Item 7: other biases. 
Table 2 Level of evidence

\begin{tabular}{|c|c|c|c|c|}
\hline Database & Reference & Number of patients & Level of evidence & $\begin{array}{l}\text { Level of } \\
\text { recommendation }\end{array}$ \\
\hline \multirow[t]{5}{*}{ Google Scholar } & Schulman et al, $2008^{23}$ & 17 & 3 & $\mathrm{D}$ \\
\hline & Shokunbi, $2014^{24}$ & 3 & 3 & $\mathrm{D}$ \\
\hline & Napadow, et al, $2004^{25}$ & 11 & $2+$ & $\mathrm{C}$ \\
\hline & Zailaa, $2010^{26}$ & 22 & $2++$ & $B$ \\
\hline & Ding and Shen, $2013^{27}$ & 38 & $2-$ & $C$ \\
\hline ScienceDirect & Wong et al., $2016^{28}$ & 181 & $2+$ & $\mathrm{C}$ \\
\hline \multirow[t]{15}{*}{ PubMed } & Dimitrova et al, $2019^{29}$ & 60 & $2++$ & B \\
\hline & Chen et al, $2017^{30}$ & 60 & $2+$ & C \\
\hline & Ural and Öztürk, $2017^{31}$ & 27 & $2+$ & $C$ \\
\hline & Maeda et al, $2017^{32}$ & 80 & $2+$ & $\mathrm{C}$ \\
\hline & Hadianfard et al, $2015^{33}$ & 50 & $2+$ & $\mathrm{C}$ \\
\hline & Maeda et al, 2013a & 67 & $2++$ & B \\
\hline & Ho et al, $2014^{35}$ & 26 & $2+$ & C \\
\hline & Maeda et al, $2013 b^{36}$ & 59 & $2++$ & $B$ \\
\hline & Khosrawi et al, $2012^{37}$ & 72 & $2+$ & C \\
\hline & Kumnerddee and Kaewtong, $2010^{38}$ & 61 & $2+$ & C \\
\hline & Yang et al, $2011^{39}$ & 77 & $2+$ & $\mathrm{C}$ \\
\hline & Yang et al, $2009^{40}$ & 77 & $2+$ & C \\
\hline & Napadow et al, $2007^{41}$ & 25 & $2++$ & $B$ \\
\hline & Napadow et al, $2006^{42}$ & 25 & $2++$ & B \\
\hline & Yao et al, $2012^{43}$ & 41 & $2+$ & C \\
\hline
\end{tabular}

Legend: $1++$ (meta-analysis of high quality, systematic review of clinical trials or high quality clinical trials with very low risk of bias), $1+$ (well performed meta-analyses, systematic reviews of clinical trials or well performed clinical trials with a low risk of bias), 1- (meta-analysis, systematic reviews of clinical trials or clinical trials with a high risk of bias), $2++$ (high quality systematic reviews of cohort studies or of cases and controls. Cohort studies or of cases and controls with a very low risk of bias and a high probability of establishing a causal relationship), 2+ (cohort or case and control studies which are well performed with low risk of bias and with a moderate probability of establishing a causal relation), 2 - (cohort or case and control studies with a high risk of bias and a significant risk for a non-causal relation), 3 (non-analytic studies, such as case reports and case series), 4 (expert opinion), A (at least one meta-analysis, systematic review or clinical trial classified as $1++$ and directly applicable to the target population of the guide; or a volume of scientific evidence comprised of studies classified as $1+$ and with large consistence among them), B (a volume of scientific evidence comprised of studies classified as $2++$, directly applicable to the target population of the guide and which demonstrate a great consistency among them; or scientific evidence extrapolated from studies classified as $1++$ or $1+$ ), C (a volume of scientific evidence comprised of studies classified as $2+$, directly applicable to the target population of the guide and which demonstrate great consistency between them; or scientific evidence extrapolated from studies classified as $2++$ ), D (level 3 or 4 scientific evidence; or scientific evidence extrapolated form studies classified as $2+$ ), $\boldsymbol{V}$ ( recommended practice based on clinical experience and consensus of the research team).

As shown on -Figure 1, in a first analysis, 622 articles were discarded by their title and abstract, failing to fulfill the inclusion criteria for this review, because of different aims or treatments. Of the 76 remaining studies, 39 were discarded (34 were duplicated in several databases, and 5 were discarded as these were systematic reviews). Of the 37 remaining articles selected, after an in-depth reading, 16 papers were discarded for the following reasons: 7 performed the study together with other therapies or drugs, 5 because of stimulation of the acupuncture point or the needle with other techniques that do not concern this study (laser, moxibustion, acupressure, cupping therapy), 3 did not fulfill the study aims because of performing other analyses, 1 performed the treatment by medical decision external to the study. Finally, 21 articles were selected for inclusion in this systematic review. The selected studies are analyzed in -Table 3.
- Table 2 shows that the level of evidence is medium with a tendency to be high and the level of recommendation is medium. Regarding the individual bias of the articles gathered in this systematic review (-Table 1; - Figure 2 ), in general, there is a risk of neutral bias, with a tendency for low bias. To a large extent, this validates the results obtained in this study.

Of the articles gathered in this review, over 95\% report favorable changes in response to the intervention with acupuncture and electroacupuncture, showing improvements in CTS (- Table 3). ${ }^{23-42}$ The only study introduced which did not show favorable changes was the study by Yao et al ( - Table 3 ). ${ }^{43}$ These authors found that the group receiving intervention with acupuncture improved at 3 months in an identical manner to the placebo group. Several studies $27,28,32,36,43$ show that changes experienced by subjects via the application of acupuncture and electroacupuncture are maintained during long 
Table 3 Analysis of results, key concepts and brief description of the articles

\begin{tabular}{|c|c|c|c|c|c|c|c|}
\hline Author, year & $\begin{array}{l}\text { Type of } \\
\text { study }\end{array}$ & $\begin{array}{l}\text { Number }(\mathrm{N}) \text { of } \\
\text { subjects and } \\
\text { stage of evolu- } \\
\text { tion }\end{array}$ & Intervention & $\begin{array}{l}\text { Duration of } \\
\text { follow-up }\end{array}$ & $\begin{array}{l}\text { Outcome mea- } \\
\text { sures }\end{array}$ & Relevant results & Conclusion \\
\hline $\begin{array}{l}\text { Schulman } \\
\text { et al, } 2008^{23}\end{array}$ & Case series & $\begin{array}{l}\mathrm{N}=17 . \text { Nerve } \\
\text { conduction im- } \\
\text { pairment: mild, } \\
\text { moderate and } \\
\text { severe. }\end{array}$ & $\begin{array}{l}\text { Needling for } \\
20 \text { minutes } \\
\text { with electrical } \\
\text { stimulation at } \\
4 \mathrm{~Hz} \text {. }\end{array}$ & $(-)$ & $\begin{array}{l}\text { Patient verbaliza- } \\
\text { tion } \\
\text { regarding the res- } \\
\text { olution of symp- } \\
\text { toms: complete, } \\
\text { partial or without } \\
\text { resolution. }\end{array}$ & $\begin{array}{l}\text { Of } 14 \text { patients } \\
\text { treated with } \\
\text { acupuncture, } 12 \\
\text { reported a } \\
\text { partial or complete } \\
\text { resolution of } \\
\text { symptoms, and } 2 \\
\text { did not obtain a } \\
\text { resolution of } \\
\text { symptoms. }\end{array}$ & $\begin{array}{l}\text { Early intervention } \\
\text { for CTS in patients } \\
\text { with mild to mod- } \\
\text { erate impairment } \\
\text { provides better } \\
\text { results than those } \\
\text { of advanced cases. }\end{array}$ \\
\hline $\begin{array}{l}\text { Shokunbi } \\
2014^{24}\end{array}$ & Case study & $\begin{array}{l}3 \text { subjects with } \\
\text { over } 3 \text { months } \\
\text { of evolution and } \\
\text { refractory to } \\
\text { other } \\
\text { non-surgical } \\
\text { treatments. }\end{array}$ & $\begin{array}{l}16 \text { sessions of } \\
\text { acupuncture } \\
\text { lasting } \\
30 \text { minutes, } \\
\text { twice a week } \\
\text { during } \\
8 \text { weeks. } \\
\text { Needling and } \\
\text { ergonomic } \\
\text { changes at } \\
\text { work. }\end{array}$ & 8 weeks. & $\begin{array}{l}\text { SSS test at base- } \\
\text { line and } 8 \text { weeks } \\
\text { after. }\end{array}$ & $\begin{array}{l}\text { SSS test: improve- } \\
\text { ment. The symp- } \\
\text { toms of waking up } \\
\text { in the middle of the } \\
\text { night were } \\
\text { eliminated. Reduc- } \\
\text { tion of the } \\
\text { intensity of pain: } \\
80 \% \text { in } 2 \text { cases. Re- } \\
\text { duction of } 50 \% \text { of: } \\
\text { paresthesia, } \\
\text { numbness, and } \\
\text { weakness. }\end{array}$ & $\begin{array}{l}\text { Acupuncture } \\
\text { treatment with er- } \\
\text { gonomic work- } \\
\text { place changes } \\
\text { improves the sub- } \\
\text { jective } \\
\text { symptoms of CTS. }\end{array}$ \\
\hline $\begin{array}{l}\text { Napadow } \\
\text { et al, } 2004^{25}\end{array}$ & $\begin{array}{l}\text { Case-control } \\
\text { study }\end{array}$ & $\begin{array}{l}\mathrm{N}=11 \text { subjects } \\
\text { with positive } \\
\text { mild to moder- } \\
\text { ate } \mathrm{CTS} \text {. } \\
\text { Intervention } \\
\text { group, } \mathrm{N}=6 \text {; } \\
\text { control group, } \\
\mathrm{N}=5 \text {. }\end{array}$ & $\begin{array}{l}\text { 5-week acu- } \\
\text { puncture } \\
\text { protocol. }\end{array}$ & $\begin{array}{l}\text { Assessment } \\
\text { before } \\
\text { the session, at } \\
2 \text { weeks and } \\
\text { after } 5 \text { weeks. }\end{array}$ & $\begin{array}{l}\text { Nerve conduction } \\
\text { somatosensory } \\
\text { evoked potential, } \\
\text { and functional } \\
\text { magnetic reso- } \\
\text { nance before, dur- } \\
\text { ing and after } \\
\text { treatment. Boston } \\
\text { questionnaire. } \\
\text { Physical exam } \\
\text { Phalen test, Tinel } \\
\text { sign, and grip } \\
\text { strength. }\end{array}$ & $\begin{array}{l}\text { Functional mag- } \\
\text { netic resonance: } \\
\text { activation of the } \\
\text { postcentral } \\
\text { gyrus of the con- } \\
\text { tralateral fingers. } \\
\text { For patients with } \\
\text { CTS, activation af- } \\
\text { ter } 5 \text { weeks of acu- } \\
\text { puncture changed } \\
\text { more for the } 2 \text { nd } \\
\text { and 3rd fingers } \\
\text { than for the } 5 \text { th } \\
\text { finger. Boston } \\
\text { questionnaire: de- } \\
\text { creasing the mean } \\
\text { severity of the } \\
\text { neuropathic symp- } \\
\text { toms of CTS. }\end{array}$ & $\begin{array}{l}\text { CTS improved } \\
\text { with acupuncture. } \\
\text { Real acupuncture } \\
\text { was superior to } \\
\text { simulated acu- } \\
\text { puncture in pe- } \\
\text { ripheral and } \\
\text { cerebral neuro- } \\
\text { physiology. Func- } \\
\text { tional magnetic } \\
\text { resonance can be } \\
\text { used to monitor } \\
\text { the cortical acti- } \\
\text { vation associated } \\
\text { with a chronic } \\
\text { neuropathy due to } \\
\text { entrapment. }\end{array}$ \\
\hline $\begin{array}{l}\text { Zailaa, } \\
2010^{26}\end{array}$ & $\begin{array}{l}\text { Case-control } \\
\text { study }\end{array}$ & $\begin{array}{l}\mathrm{N}=22 \text { subjects } \\
\text { with } \\
\text { documented } \\
\text { history of } \mathrm{CTS} \text {, } \\
\text { assessed using } \\
\text { magnetic } \\
\text { resonance. }\end{array}$ & $\begin{array}{l}\text { Application of } \\
\text { a small dose of } \\
\text { neutral liquid } \\
\text { on } \\
\text { acupuncture } \\
\text { points. }\end{array}$ & $\begin{array}{l}\text { The following } \\
\text { six hours after } \\
\text { the intervention } \\
\text { with functional } \\
\text { magnetic } \\
\text { resonance } \\
\text { assessment. }\end{array}$ & $\begin{array}{l}\text { Structural images } \\
\text { of the wrist in high } \\
\text { resolution } 4 T \text { of } \\
\text { the median nerve. } \\
\text { Grouped function- } \\
\text { al magnetic } \\
\text { resonance data, } \\
\text { BOLD-contrast im- } \\
\text { aging response. }\end{array}$ & $\begin{array}{l}\text { All of the subjects } \\
\text { reported a moder- } \\
\text { ate sensation of } \\
\text { electric tingling. } \\
\text { Functional reso- } \\
\text { nance; no signifi- } \\
\text { cant BOLD- } \\
\text { contrast } \\
\text { imaging response } \\
\text { was found to the } \\
\text { stimulations on } \\
\text { both points. Medi- } \\
\text { an nerve without } \\
\text { structural changes. }\end{array}$ & $\begin{array}{l}\text { Statistically signif- } \\
\text { icant reduction in } \\
\text { the intensity of } \\
\text { the signal and the } \\
\text { inflammation } \\
\text { within the median } \\
\text { nerve after } \\
\text { acupuncture. }\end{array}$ \\
\hline $\begin{array}{l}\text { Ding and } \\
\text { Shen, } 2013^{27}\end{array}$ & $\begin{array}{l}\text { Randomized } \\
\text { controlled } \\
\text { trial }\end{array}$ & $\begin{array}{l}\mathrm{N}=38 \text { Inter- } \\
\text { vention group: } \\
\mathrm{N}=19 \text { Control } \\
\text { group. }\end{array}$ & $\begin{array}{l}\text { Group C: } \\
\text { moxibustion } \\
\text { performed on } \\
\text { the Yangchi } \\
\text { point. Group I: } \\
\text { electric acu- } \\
\text { puncture on } \\
\text { the Yangchi } \\
\text { point. }\end{array}$ & 3 months. & $\begin{array}{l}\text { VAS assessments, } \\
\text { SSS before and af- } \\
\text { ter treatment }\end{array}$ & $\begin{array}{l}\text { VAS, SSS assess- } \\
\text { ments: improve- } \\
\text { ments compared } \\
\text { to the same group } \\
\text { before treatment } \\
\text { in favor of the acu- } \\
\text { puncture group. } \\
3 \text { months later: the } \\
\text { VAS scores did not } \\
\text { show differences } \\
\text { between both } \\
\text { groups; the SSS } \\
\text { scores showed dif- } \\
\text { ferences for the }\end{array}$ & $\begin{array}{l}\text { Acupuncture } \\
\text { improves pain, } \\
\text { numbness and } \\
\text { motor activity } \\
\text { in patients with } \\
\text { CTS. }\end{array}$ \\
\hline
\end{tabular}


18 Acupuncture and electroacupuncture in the treatment of carpal tunnel syndrome Badia, Santafé

Table 3 (Continued)

\begin{tabular}{|c|c|c|c|c|c|c|c|}
\hline Author, year & $\begin{array}{l}\text { Type of } \\
\text { study }\end{array}$ & $\begin{array}{l}\text { Number }(\mathrm{N}) \text { of } \\
\text { subjects and } \\
\text { stage of evolu- } \\
\text { tion }\end{array}$ & Intervention & $\begin{array}{l}\text { Duration of } \\
\text { follow-up }\end{array}$ & $\begin{array}{l}\text { Outcome mea- } \\
\text { sures }\end{array}$ & Relevant results & Conclusion \\
\hline & & & & & & $\begin{array}{l}\text { acupuncture } \\
\text { group. }\end{array}$ & \\
\hline $\begin{array}{l}\text { Wong et al, } \\
2016^{28}\end{array}$ & $\begin{array}{l}\text { Randomized } \\
\text { controlled } \\
\text { trial }\end{array}$ & $\begin{array}{l}\mathrm{N}=181 \text {. Elec- } \\
\text { troacupuncture } \\
\text { + nocturnal } \\
\text { splinting: } \\
\mathrm{N}=90 . \text { Control } \\
\text { group: } \mathrm{N}=91 ; \\
\text { only nocturnal } \\
\text { splinting. }\end{array}$ & $\begin{array}{l}\text { Electroacu- } \\
\text { puncture } \\
(10-20 \mathrm{~mA} \text {, } \\
20-40 \mathrm{~Hz} \text {, } \\
\text { continuous } \\
\text { wave) on the } \\
\text { affected side } \\
\text { in } 20 \text {-minute } \\
\text { sessions dur- } \\
\text { ing } 17 \text { weeks, } \\
\text { with a total of } \\
13 \text { sessions. }\end{array}$ & 17 weeks. & $\begin{array}{l}\text { Boston question- } \\
\text { naire; DASH ques- } \\
\text { tionnaire. Pain } \\
\text { intensity, } \\
\text { strength, fingertip } \\
\text { pinch measured } \\
\text { with a } \\
\text { dynamometer of } \\
\text { therapeutic pinch; } \\
\text { Sensation of pain; } \\
\text { Semmes-Wein- } \\
\text { stein monofila- } \\
\text { ment examina- } \\
\text { tion; Dexterity: } \\
\text { Moberg pick-up } \\
\text { test (modified by } \\
\text { Dellon). }\end{array}$ & $\begin{array}{l}\text { Boston and DASH } \\
\text { questionnaires: } \\
\text { improvement. For } \\
\text { pain intensity: re- } \\
\text { duction of pain. } \\
\text { Dexterity, strength } \\
\text { and sensation of } \\
\text { pain: greater pro- } \\
\text { portion of patients } \\
\text { with improvement. }\end{array}$ & $\begin{array}{l}\text { Electroacupunc- } \\
\text { ture improves the } \\
\text { symptoms of the } \\
\text { disability function, } \\
\text { dexterity and } \\
\text { strength in a 17- } \\
\text { week assessment, } \\
\text { in combination } \\
\text { with nocturnal } \\
\text { splinting. }\end{array}$ \\
\hline $\begin{array}{l}\text { Dimitrova } \\
\text { et al, } 2019^{29}\end{array}$ & $\begin{array}{l}\text { Mechanical } \\
\text { pilot study }\end{array}$ & $\begin{array}{l}\mathrm{N}=60 \text {. Mild to } \\
\text { moderate CTS } \\
\text { based on EMG. } \\
\text { Group 1: manu- } \\
\text { al acupuncture. } \\
\text { Group 2: low } \\
\text { frequency elec- } \\
\text { troacupunc- } \\
\text { ture. Group 3: } \\
\text { high } \\
\text { frequency elec- } \\
\text { troacupunc- } \\
\text { ture. }\end{array}$ & $\begin{array}{l}\text { Needling on } \\
\text { points of the } \\
\text { pericardial } \\
\text { nerve and } \\
\text { heart associat- } \\
\text { ed with the } \\
\text { median and ul- } \\
\text { nar nerves re- } \\
\text { spectively. Two } \\
\text { treatments: } \\
\text { acupuncture } \\
\text { on the median } \\
\text { nerve-pericar- } \\
\text { dium meridian } \\
\text { and ulnar } \\
\text { nerve-heart } \\
\text { meridian, with } \\
\text { one week in } \\
\text { between. }\end{array}$ & 2 weeks. & $\begin{array}{l}\text { Assessment of } \\
\text { sensory nerve } \\
\text { conduction and } \\
\text { qualitative senso- } \\
\text { ry test (assess- } \\
\text { ment of cold and } \\
\text { vibration } \\
\text { threshold); postin- } \\
\text { tervention in the } \\
\text { median and ulnar } \\
\text { nerve compared } \\
\text { to } \\
\text { preintervention } \\
\text { measures. }\end{array}$ & $\begin{array}{l}\text { Group 1: improve- } \\
\text { ment of the } \\
\text { threshold for de- } \\
\text { tection of cold in } \\
\text { the median nerve, } \\
\text { but not in the } \\
\text { healthy ulnar } \\
\text { nerve. Group 2: } \\
\text { recovery of action } \\
\text { potentials of the } \\
\text { sensory median } \\
\text { nerve. Group } 3: \\
\text { improvement of } \\
\text { the sensation of } \\
\text { cold of the median } \\
\text { nerve and vibration } \\
\text { with increased } \\
\text { conduction veloci- } \\
\text { ty of the sensory } \\
\text { and motor median } \\
\text { nerves. }\end{array}$ & $\begin{array}{l}\text { Acupuncture has a } \\
\text { specific } \\
\text { effect on the me- } \\
\text { dian and ulnar } \\
\text { nerves of the } \\
\text { forearm, which } \\
\text { can be measured } \\
\text { with a nerve } \\
\text { conduction test } \\
\text { and quantitative } \\
\text { sensory test. }\end{array}$ \\
\hline $\begin{array}{l}\text { Chen et al, } \\
2017^{30}\end{array}$ & $\begin{array}{l}\text { Case-control } \\
\text { study }\end{array}$ & $\begin{array}{l}\mathrm{N}=60 \text { subjects } \\
\text { with mild to } \\
\text { moderate } \mathrm{CTS} \text {. } \\
\text { Control group: } \\
\mathrm{N}=30 ; \text { Case } \\
\text { group: } \mathrm{N}=30 \text {. }\end{array}$ & $\begin{array}{l}\text { Case group: } \\
\text { needling on } \\
\text { the contralat- } \\
\text { eral side and } \\
\text { then needling } \\
\text { on the affect- } \\
\text { ed side. Con- } \\
\text { trol group: } \\
\text { acupuncture } \\
\text { on the points } \\
\text { of the affect- } \\
\text { ed side. } 10- \\
\text { day treat- } \\
\text { ment, with } \\
\text { acupuncture } \\
\text { once a day for } \\
30 \text { minutes. }\end{array}$ & 10 days. & $\begin{array}{l}3 \text { sessions. } \\
\text { Electrophysiology } \\
\text { of the median } \\
\text { nerve. CTS ques- } \\
\text { tionnaire by Lev- } \\
\text { ine. Wrist } \\
\text { assessment classi- } \\
\text { fied by the } \\
\text { patients. }\end{array}$ & $\begin{array}{l}\text { Effectiveness of } \\
90 \% \text { in the } \\
\text { observation group, } \\
\text { and of } 70 \% \text { in the } \\
\text { control group. The } \\
\text { velocity of the } \\
\text { sensory conduc- } \\
\text { tion and the am- } \\
\text { plitude of the } \\
\text { median nerve in- } \\
\text { creased in both } \\
\text { groups. }\end{array}$ & $\begin{array}{l}\text { The combined } \\
\text { treatment with } \\
\text { the technique of } \\
\text { homo and contra- } \\
\text { lateral acupunc- } \\
\text { ture achieves } \\
\text { therapeutic } \\
\text { effects in cases of } \\
\text { mild to moderate } \\
\text { CTS, which are } \\
\text { superior to those } \\
\text { of the regular } \\
\text { needling } \\
\text { technique. }\end{array}$ \\
\hline $\begin{array}{l}\text { Ural and } \\
\text { Öztürk, } \\
2017^{31}\end{array}$ & $\begin{array}{l}\text { Case-control } \\
\text { study }\end{array}$ & $\begin{array}{l}\mathrm{N}=27 \text { women } \\
\text { diagnosed with } \\
\text { CTS by EMG. } \\
\text { Control group: } \\
\text { treatment with } \\
\text { nocturnal } \\
\text { splinting. Case } \\
\text { group: treat- } \\
\text { ment with } \\
\text { nocturnal } \\
\text { splinting plus } \\
\text { acupuncture. }\end{array}$ & $\begin{array}{l}\text { Acupuncture } \\
\text { was per- } \\
\text { formed during } \\
10 \text { sessions } \\
\text { lasting } \\
25 \text { minutes } \\
\text { each; } 2 \text { or } \\
3 \text { sessions per } \\
\text { week. }\end{array}$ & 4 weeks & $\begin{array}{l}\text { Visual scale for the } \\
\text { severity of the } \\
\text { symptoms. Dur- } \\
\text { uoz Hand Index } \\
\text { and DASH ques- } \\
\text { tionnaire for hand } \\
\text { function and dis- } \\
\text { ability. Electro- } \\
\text { physiology: mus- } \\
\text { cle action } \\
\text { potential, speed of } \\
\text { motor and sensory } \\
\text { nerve conduction, }\end{array}$ & $\begin{array}{l}\text { All of the param- } \\
\text { eters improved in } \\
\text { both groups. The } \\
\text { diameter of the } \\
\text { median nerve de- } \\
\text { creased in the acu- } \\
\text { puncture group. } \\
\text { The changes were } \\
\text { greater in the acu- } \\
\text { puncture group } \\
\text { than in the control } \\
\text { group. }\end{array}$ & $\begin{array}{l}\text { The diameter of } \\
\text { the median nerve } \\
\text { decreased after } \\
\text { treatment with } \\
\text { acupuncture, as } \\
\text { well as the severity } \\
\text { of the symptoms, } \\
\text { the functions of } \\
\text { the hand and the } \\
\text { electromyograph- } \\
\text { ic measurements, } \\
\text { which were more } \\
\text { significant in the }\end{array}$ \\
\hline
\end{tabular}


Table 3 (Continued)

\begin{tabular}{|c|c|c|c|c|c|c|c|}
\hline Author, year & $\begin{array}{l}\text { Type of } \\
\text { study }\end{array}$ & $\begin{array}{l}\text { Number }(\mathrm{N}) \text { of } \\
\text { subjects and } \\
\text { stage of evolu- } \\
\text { tion }\end{array}$ & Intervention & $\begin{array}{l}\text { Duration of } \\
\text { follow-up }\end{array}$ & $\begin{array}{l}\text { Outcome mea- } \\
\text { sures }\end{array}$ & Relevant results & Conclusion \\
\hline & & & & & $\begin{array}{l}\text { distal motor la- } \\
\text { tency. } \\
\text { Ultrasound: diam- } \\
\text { eter of the median } \\
\text { nerve. }\end{array}$ & & $\begin{array}{l}\text { acupuncture } \\
\text { group. }\end{array}$ \\
\hline $\begin{array}{l}\text { Maeda et al, } \\
2017^{32}\end{array}$ & $\begin{array}{l}\text { Randomized } \\
\text { clinical trial }\end{array}$ & $\begin{array}{l}\mathrm{N}=80 \text { : group } \\
\text { of real local } \\
\text { electroacupunc- } \\
\text { ture on the af- } \\
\text { fected hand; } \\
\text { group of real } \\
\text { electroacupunc- } \\
\text { ture distal in the } \\
\text { ankle contrale- } \\
\text { sional to the af- } \\
\text { fected hand; } \\
\text { and group of } \\
\text { simulated elec- } \\
\text { troacupuncture } \\
\text { with a non-pen- } \\
\text { etrating sham } \\
\text { needle. }\end{array}$ & $\begin{array}{l}\text { The } 3 \text { groups } \\
\text { underwent } \\
16 \text { sessions of } \\
\text { electroacu- } \\
\text { puncture dur- } \\
\text { ing } 8 \text { weeks. }\end{array}$ & 3 months. & $\begin{array}{l}\text { Boston question- } \\
\text { naire: scoring of } \\
\text { pain and pares- } \\
\text { thesia at the be- } \\
\text { ginning of the } \\
\text { study, after treat- } \\
\text { ment, and during } \\
\text { the } 3 \text { months of } \\
\text { follow-up. Deter- } \\
\text { mination of the } \\
\text { sensory latency of } \\
\text { the nerve. Func- } \\
\text { tional magnetic } \\
\text { resonance of the } \\
\text { somatosensory } \\
\text { cortex at the be- } \\
\text { ginning of the } \\
\text { study and after } \\
\text { therapy. }\end{array}$ & $\begin{array}{l}\text { The three groups } \\
\text { displayed an im- } \\
\text { provement in the } \\
\text { severity of symp- } \\
\text { toms. Neurophysi- } \\
\text { ology: real local } \\
\text { and distal electro- } \\
\text { acupuncture was } \\
\text { superior to simu- } \\
\text { lated electroacu- } \\
\text { puncture. The } \\
\text { greatest improve- } \\
\text { ment in the dis- } \\
\text { tance of cortical } \\
\text { separation oc- } \\
\text { curred } \\
\text { between digits } 2 \\
\text { and } 3 \text { in real elec- } \\
\text { troacupuncture at } \\
3 \text { months of follow- } \\
\text { up. }\end{array}$ & $\begin{array}{l}\text { Acupuncture on } \\
\text { local sites versus } \\
\text { distal sites can } \\
\text { improve the func- } \\
\text { tion of the median } \\
\text { nerve at the wrist } \\
\text { by somatotopic } \\
\text { neuroplasticity, } \\
\text { different at the } \\
\text { level of the prima- } \\
\text { ry } \\
\text { somatosensory } \\
\text { cortex after } \\
\text { therapy. }\end{array}$ \\
\hline $\begin{array}{l}\text { Hadianfard } \\
\text { et al, } 2015^{33}\end{array}$ & $\begin{array}{l}\text { Case-control } \\
\text { study }\end{array}$ & $\begin{array}{l}\mathrm{N}=50 \text { subjects } \\
\text { with mild to } \\
\text { moderate CTS. } \\
\text { Ibuprofen } \\
\text { group, } \mathrm{N}=25 \text {. } \\
\text { Acupuncture } \\
\text { group, } \mathrm{N}=25 \text {. }\end{array}$ & $\begin{array}{l}\text { Both groups } \\
\text { were submit- } \\
\text { ted to noctur- } \\
\text { nal splinting. } \\
\text { Acupuncture } \\
\text { group: } 8 \text { ses- } \\
\text { sions for } \\
20 \text { minutes } \\
\text { twice a week } \\
\text { during } \\
4 \text { weeks. The } \\
\text { Ibuprofen } \\
\text { group received } \\
400 \text { mg of ibu- } \\
\text { profen } 3 \text { times } \\
\text { a day during } \\
10 \text { days. }\end{array}$ & 1 month & $\begin{array}{l}\text { VAS score, Boston } \\
\text { questionnaire, } \\
\text { BCQT FUNCT and } \\
\text { BCQT SYMPT. } \\
\text { Electrophysiology } \\
\text { at the beginning } \\
\text { and end of the } \\
\text { treatment. }\end{array}$ & $\begin{array}{l}\text { Significant improve- } \\
\text { ments in both } \\
\text { groups with greater } \\
\text { significance in the } \\
\text { acupuncture group. } \\
\text { The scores on the } \\
\text { BCTQ, FUNCT, } \\
\text { global SYMPT, VAS, } \\
\text { and electrophysio- } \\
\text { logical findings were } \\
\text { superior in the acu- } \\
\text { puncture group } \\
\text { compared with the } \\
\text { ibuprofen group. }\end{array}$ & $\begin{array}{l}\text { Acupuncture } \\
\text { could be an } \\
\text { effective treat- } \\
\text { ment for CTS. }\end{array}$ \\
\hline $\begin{array}{l}\text { Maeda et al, } \\
2013 a^{34}\end{array}$ & $\begin{array}{l}\text { Case-control } \\
\text { study }\end{array}$ & $\begin{array}{l}\mathrm{N}=67 . \mathrm{CTS} \\
\text { group, } \mathrm{N}=37 ; \\
\text { group of } \\
\text { healthy sub- } \\
\text { jects } \mathrm{N}=30 .\end{array}$ & $\begin{array}{l}\text { Electroacu- } \\
\text { puncture at } \\
2 \mathrm{~Hz} \text { on the } \\
\text { affected wrist } \\
\text { and dominant } \\
\text { hand in } \\
\text { healthy sub- } \\
\text { jects. Distal } \\
\text { acupuncture } \\
\text { on the contra- } \\
\text { lateral leg in } \\
\text { relation to the } \\
\text { most affected } \\
\text { hand with CTS } \\
\text { or dominant } \\
\text { in healthy } \\
\text { subjects. }\end{array}$ & $(-)$ & $\begin{array}{l}\text { Data of structural } \\
\text { image via weight- } \\
\text { ed pulse sequence } \\
\text { of multiple } \\
\text { captures. }\end{array}$ & $\begin{array}{l}\text { The brain response } \\
\text { in both groups and } \\
\text { acupuncture } \\
\text { points included the } \\
\text { activation of the } \\
\text { contralesional so- } \\
\text { matosensory cor- } \\
\text { tex. } \\
\text { Difference be- } \\
\text { tween points of } \\
\text { local and distal } \\
\text { acupuncture for } \\
\text { healthy subjects, } \\
\text { but not for } \\
\text { subjects with CTS. } \\
\text { No correlation was } \\
\text { found between } \\
\text { distal } \\
\text { acupuncture } \\
\text { points for any of } \\
\text { the groups. }\end{array}$ & $\begin{array}{l}\text { The brain re- } \\
\text { sponse to electro- } \\
\text { acupuncture dif- } \\
\text { fers among } \\
\text { subjects with CTS } \\
\text { and healthy sub- } \\
\text { jects for the local } \\
\text { stimulation of the } \\
\text { acupuncture } \\
\text { point. }\end{array}$ \\
\hline $\begin{array}{l}\text { Ho et al, } \\
2014^{35}\end{array}$ & $\begin{array}{l}\text { Case-control } \\
\text { study }\end{array}$ & $\begin{array}{l}\mathrm{N}=26 . \text { Acu- } \\
\text { puncture } \\
\text { group, } \mathrm{N}=15 ; \\
\text { electroacupunc- } \\
\text { ture group, } \\
\mathrm{N}=11 .\end{array}$ & $\begin{array}{l}24 \text { sessions of } \\
\text { acupuncture } \\
\text { for } 15 \text { minutes } \\
\text { during } \\
6 \text { weeks. }\end{array}$ & 6 weeks. & $\begin{array}{l}\text { Short clinical } \\
\text { questionnaire by } \\
\text { LO and Chiang; } \\
\text { electrophysiologi- } \\
\text { cal }\end{array}$ & $\begin{array}{l}\text { Improved scores } \\
\text { for symptoms after } \\
\text { treatment with } \\
\text { electroacupunc- } \\
\text { ture. }\end{array}$ & $\begin{array}{l}\text { Electroacupunc- } \\
\text { ture can improve } \\
\text { symptoms. }\end{array}$ \\
\hline
\end{tabular}


20 Acupuncture and electroacupuncture in the treatment of carpal tunnel syndrome Badia, Santafé

Table 3 (Continued)

\begin{tabular}{|c|c|c|c|c|c|c|c|}
\hline Author, year & $\begin{array}{l}\text { Type of } \\
\text { study }\end{array}$ & $\begin{array}{l}\text { Number }(\mathrm{N}) \text { of } \\
\text { subjects and } \\
\text { stage of evolu- } \\
\text { tion }\end{array}$ & Intervention & $\begin{array}{l}\text { Duration of } \\
\text { follow-up }\end{array}$ & $\begin{array}{l}\text { Outcome mea- } \\
\text { sures }\end{array}$ & Relevant results & Conclusion \\
\hline & & & & & $\begin{array}{l}\text { assessment; Tinel } \\
\text { sign. }\end{array}$ & & \\
\hline $\begin{array}{l}\text { Khosrawi } \\
\text { et al, } 2012^{36}\end{array}$ & $\begin{array}{l}\text { Case-control } \\
\text { study }\end{array}$ & $\begin{array}{l}\mathrm{N}=72 \text {. Control } \\
\text { group }(\mathrm{N}=32) \text { : } \\
\text { nocturnal } \\
\text { splinting, vita- } \\
\text { mins } \mathrm{B} 1 \text { and } \mathrm{B} 6 \text {; } \\
\text { Case group } \\
(\mathrm{N}=32) \text { : } \\
\text { acupuncture. }\end{array}$ & $\begin{array}{l}\text { Control } \\
\text { group: inter- } \\
\text { vention with } \\
\text { nocturnal } \\
\text { splinting, } \\
\text { vitamin B1 } \\
\text { and B6 and } \\
\text { simulated } \\
\text { acupuncture } \\
\text { during } \\
5 \text { weeks. Case } \\
\text { group: } 8 \text { ses- } \\
\text { sions of acu- } \\
\text { puncture and } \\
\text { nocturnal } \\
\text { splinting } \\
\text { during } \\
4 \text { weeks. }\end{array}$ & 4 weeks. & $\begin{array}{l}\text { Global score of } \\
\text { clinical symptoms; } \\
\text { SSS; electrophysi- } \\
\text { ology. }\end{array}$ & $\begin{array}{l}\text { Case group: im- } \\
\text { provement in the } \\
\text { SSS and } \\
\text { electrophysiology. }\end{array}$ & $\begin{array}{l}\text { Acupuncture } \\
\text { improves the } \\
\text { symptoms of CTS. }\end{array}$ \\
\hline $\begin{array}{l}\text { Kumnerddee } \\
\text { et al, } 2010^{38}\end{array}$ & $\begin{array}{l}\text { Randomized } \\
\text { clinical trial }\end{array}$ & $\begin{array}{l}\mathrm{N}=61 \text { subjects } \\
\text { with mild to } \\
\text { moderate CTS. } \\
\text { Acupuncture } \\
\text { group; noctur- } \\
\text { nal splinting } \\
\text { group. }\end{array}$ & $\begin{array}{l}\text { Acupuncture } \\
\text { group: } \\
10 \text { sessions of } \\
\text { electroacu- } \\
\text { puncture } \\
\text { twice a week; } \\
\text { nocturnal } \\
\text { splinting } \\
\text { group: neutral } \\
\text { wrist splint } \\
\text { worn each } \\
\text { night. }\end{array}$ & 5 weeks. & $\begin{array}{l}\text { BCTQ, SSS, FSS, } \\
\text { VAS. }\end{array}$ & $\begin{array}{l}\text { VAS score: de- } \\
\text { creased in the } \\
\text { acupuncture group } \\
\text { compared with the } \\
\text { nocturnal splint- } \\
\text { ing. There were no } \\
\text { differences in the } \\
\text { SSS and FSS be- } \\
\text { tween the groups. }\end{array}$ & $\begin{array}{l}\text { Electroacupunc- } \\
\text { ture reduced pain } \\
\text { more than noctur- } \\
\text { nal splinting in } \\
\text { cases of mild and } \\
\text { moderate CTS. }\end{array}$ \\
\hline $\begin{array}{l}\text { Yang et al, } \\
2011^{39}\end{array}$ & $\begin{array}{l}\text { Randomized } \\
\text { controlled } \\
\text { trial }\end{array}$ & $\begin{array}{l}\mathrm{N}=77 . \text { Mild to } \\
\text { moderate idio- } \\
\text { pathic CTS con- } \\
\text { firmed with } \\
\text { electrophysiolo- } \\
\text { gy. Prednisone } \\
\text { group, } \mathrm{n}=39 ; \\
\text { acupuncture } \\
\text { group, } \mathrm{n}=38 \text {. }\end{array}$ & $\begin{array}{l}\text { Prednisone } \\
\text { group: } \\
2 \text { weeks with } \\
20 \text { mg of } \\
\text { prednisone a } \\
\text { day followed } \\
\text { by } 2 \text { weeks of } \\
10 \text { mg of } \\
\text { prednisone a } \\
\text { day during } \\
4 \text { weeks; acu- } \\
\text { puncture } \\
\text { group: } 8 \text { ses- } \\
\text { sions during } \\
4 \text { weeks. }\end{array}$ & 13 months. & $\begin{array}{l}\text { Follow-up at } 7 \text { and } \\
13 \text { months using } \\
\text { the } \\
\text { assessment of } \\
\text { global } \\
\text { symptoms, SSS, } \\
\text { repeated nerve } \\
\text { conduction tests. }\end{array}$ & $\begin{array}{l}\text { Acupuncture } \\
\text { group compared to } \\
\text { the prednisone } \\
\text { group: improve- } \\
\text { ment in SSS, distal } \\
\text { motor latencies } \\
\text { and distal sensory } \\
\text { latencies. } \\
\text { A significant corre- } \\
\text { lation was } \\
\text { observed between } \\
\text { the SSS changed } \\
\text { from month } 13 \text { to } \\
\text { the baseline and all } \\
\text { of the electrophys- } \\
\text { iological param- } \\
\text { eters, except the } \\
\text { amplitude of the } \\
\text { composed muscle } \\
\text { action potential }\end{array}$ & $\begin{array}{l}\text { Treatment with } \\
\text { acupuncture in } \\
\text { the short term } \\
\text { improves mild to } \\
\text { moderate idio- } \\
\text { pathic CTS in the } \\
\text { long term. }\end{array}$ \\
\hline $\begin{array}{l}\text { Yang et al, } \\
2009^{40}\end{array}$ & $\begin{array}{l}\text { Randomized } \\
\text { controlled } \\
\text { trial }\end{array}$ & $\begin{array}{l}\mathrm{N}=77 \text {. Patients } \\
\text { with mild to } \\
\text { moderate idio- } \\
\text { pathic CTS di- } \\
\text { agnosed with } \\
\text { studies of nerve } \\
\text { conduction. } \\
\text { Acupuncture } \\
\text { group: } \mathrm{N}=38 \text {; } \\
\text { prednisone } \\
\text { group: } \mathrm{N}=39 \text {. }\end{array}$ & $\begin{array}{l}\text { Acupuncture } \\
\text { group: } \\
8 \text { sessions } \\
\text { during } \\
4 \text { weeks. } \\
\text { Prednisone } \\
\text { group: } 20 \mathrm{mg} \\
\text { a day during } \\
2 \text { weeks, and } \\
10 \text { mg a day } \\
\text { during the } \\
2 \text { following } \\
\text { weeks. }\end{array}$ & 4 weeks. & $\begin{array}{l}\text { SSS questionnaire } \\
\text { on weeks } 2 \text { and } 4 . \\
\text { Neurophysiology } \\
\text { at the end of the } \\
\text { study. }\end{array}$ & $\begin{array}{l}\text { SSS: a high per- } \\
\text { centage of } \\
\text { improvement in } \\
\text { both groups; how- } \\
\text { ever, without dif- } \\
\text { ferences } \\
\text { between both } \\
\text { groups. The } \\
\text { acupuncture group } \\
\text { compared to the } \\
\text { prednisone group: } \\
\text { decrease in distal } \\
\text { motor latency in } \\
\text { week } 4 \text {. }\end{array}$ & $\begin{array}{l}\text { Treatment with } \\
\text { acupuncture in } \\
\text { the short term is } \\
\text { as effective as } \\
\text { prednisone in the } \\
\text { short term for the } \\
\text { treatment of mild } \\
\text { to } \\
\text { moderate CTS. }\end{array}$ \\
\hline $\begin{array}{l}\text { Napadow } \\
\text { et al, } 2007 a^{41}\end{array}$ & $\begin{array}{l}\text { Case-control } \\
\text { study }\end{array}$ & $\begin{array}{l}\mathrm{N}=25 . \mathrm{CTS} \\
\text { group: } \mathrm{N}=13 ; \\
\text { Group of }\end{array}$ & $\begin{array}{l}\text { Electroacu- } \\
\text { puncture dur- } \\
\text { ing }\end{array}$ & 5 weeks. & $\begin{array}{l}\text { Functional mag- } \\
\text { netic resonance. }\end{array}$ & $\begin{array}{l}\text { Real acupuncture } \\
\text { activates the hypo- } \\
\text { thalamus and }\end{array}$ & $\begin{array}{l}\text { Patients with } \\
\text { chronic pain } \\
\text { respond to }\end{array}$ \\
\hline
\end{tabular}


Table 3 (Continued)

\begin{tabular}{|c|c|c|c|c|c|c|c|}
\hline Author, year & $\begin{array}{l}\text { Type of } \\
\text { study }\end{array}$ & $\begin{array}{l}\text { Number }(\mathrm{N}) \text { of } \\
\text { subjects and } \\
\text { stage of evolu- } \\
\text { tion }\end{array}$ & Intervention & $\begin{array}{l}\text { Duration of } \\
\text { follow-up }\end{array}$ & $\begin{array}{l}\text { Outcome mea- } \\
\text { sures }\end{array}$ & Relevant results & Conclusion \\
\hline & & $\begin{array}{l}\text { healthy sub- } \\
\text { jects: } N=12 \text {. }\end{array}$ & $\begin{array}{l}10 \text { minutes at } \\
2 \mathrm{~Hz} \text {. Treat- } \\
\text { ment } 3 \text { times } \\
\text { ar week dur- } \\
\text { ing } 3 \text { weeks } \\
\text { and } 2 \text { times a } \\
\text { week during } \\
\text { the last } \\
2 \text { weeks. Elec- } \\
\text { troacupunc- } \\
\text { ture in } \\
\text { patients with } \\
\text { CTS in the } \\
\text { affected } \\
\text { hand. Electro- } \\
\text { acupuncture } \\
\text { in the domi- } \\
\text { nant hand in } \\
\text { healthy } \\
\text { subjects. }\end{array}$ & & & $\begin{array}{l}\text { deactivates the } \\
\text { amygdala. Acu- } \\
\text { puncture inversely } \\
\text { activates the hypo- } \\
\text { thalamus and the } \\
\text { amygdala. The hy- } \\
\text { pothalamus re- } \\
\text { sponse was } \\
\text { positively correlat- } \\
\text { ed with the level of } \\
\text { adapted cortical } \\
\text { plasticity in } \\
\text { patients with CTS. }\end{array}$ & $\begin{array}{l}\text { acupuncture in a } \\
\text { different way } \\
\text { compared to } \\
\text { healthy subjects } \\
\text { via the limbic sys- } \\
\text { tem, which } \\
\text { includes the } \\
\text { hypothalamus and } \\
\text { the amygdala. }\end{array}$ \\
\hline $\begin{array}{l}\text { Napadow } \\
\text { et al, } 2007 b^{42}\end{array}$ & $\begin{array}{l}\text { Case-control } \\
\text { study }\end{array}$ & $\begin{array}{l}\mathrm{N}=25 . \mathrm{CTS} \\
\text { group: } \mathrm{N}=13 ; \\
\text { group of } \\
\text { healthy sub- } \\
\text { jects: } \mathrm{N}=12 \text {. }\end{array}$ & $\begin{array}{l}\text { Sensory stim- } \\
\text { ulation during } \\
\text { the imaging } \\
\text { test. Electroa- } \\
\text { cupuncture at } \\
2 \mathrm{~Hz} \text { during } \\
10 \text { minutes, } 3 \\
\text { times a week, } \\
\text { for the first } \\
\text { three weeks, } \\
\text { and twice a } \\
\text { week during } \\
\text { the remaining } \\
2 \text { weeks. }\end{array}$ & 5 weeks & $\begin{array}{l}\text { Functional magnet- } \\
\text { ic } \\
\text { resonance. Electro- } \\
\text { physiology of the } \\
\text { ulnar and median } \\
\text { nerve. } \\
\text { Grip strength, sen- } \\
\text { sory threshold test- } \\
\text { ing with Semmes- } \\
\text { Weisntein monofi- } \\
\text { ament } \\
\text { examination and } \\
\text { Phalen and } \\
\text { Tinel tests. CTS test } \\
\text { BCTQ. }\end{array}$ & $\begin{array}{l}\text { Acupuncture im- } \\
\text { proved all of the } \\
\text { subjective and ob- } \\
\text { jective } \\
\text { measures. Upon } \\
\text { functional } \\
\text { magnetic reso- } \\
\text { nance, it was } \\
\text { observed that acu- } \\
\text { puncture } \\
\text { activated the corti- } \\
\text { cal areas of the } \\
\text { median nerve, but } \\
\text { decreased the acti- } \\
\text { vation in the con- } \\
\text { tralateral precen- } \\
\text { tral and } \\
\text { postcentral gyrus, } \\
\text { in the prefrontal } \\
\text { parietal cortex and } \\
\text { the inferior dorso- } \\
\text { lateral cortex. }\end{array}$ & $\begin{array}{l}\text { Electroacupunc- } \\
\text { ture provokes a } \\
\text { stimulus of so- } \\
\text { matosensory } \\
\text { conditioning. }\end{array}$ \\
\hline $\begin{array}{l}\text { Yao et al, } \\
2012^{43}\end{array}$ & $\begin{array}{l}\text { Randomized } \\
\text { controlled } \\
\text { trial }\end{array}$ & $\begin{array}{l}\mathrm{N}=41 . \text { Acu- } \\
\text { puncture } \\
\text { group: } \mathrm{N}=21 ; \\
\text { simulated acu- } \\
\text { puncture (pla- } \\
\text { cebo): } \mathrm{N}=20 .\end{array}$ & $\begin{array}{l}\text { Noctural } \\
\text { splints for } \\
\text { both groups. } \\
6 \text { weekly ses- } \\
\text { sions of } \\
20 \text { minutes of } \\
\text { acupuncture } \\
\text { on the affect- } \\
\text { ed and con- } \\
\text { tralateral side. }\end{array}$ & 3 months & $\begin{array}{l}\text { Symptoms and } \\
\text { function domains } \\
\text { of the self-assess- } \\
\text { ment scale of the } \\
\text { carpal tunnel } \\
\text { CTSAQ. Pinch } \\
\text { strength. Com- } \\
\text { bined sensory } \\
\text { index. }\end{array}$ & $\begin{array}{l}\text { Acupuncture } \\
\text { group and placebo } \\
\text { group: improve- } \\
\text { ment in symptom } \\
\text { domain } 3 \text { months } \\
\text { after the last } \\
\text { treatment. }\end{array}$ & $\begin{array}{l}\text { Acupuncture is } \\
\text { not a better treat- } \\
\text { ment than simu- } \\
\text { lated } \\
\text { acupuncture when } \\
\text { used with the } \\
\text { splint for patients } \\
\text { with mild to mod- } \\
\text { erate CTS. }\end{array}$ \\
\hline
\end{tabular}

Abbreviations: BCTQ, Boston carpal tunnel syndrome questionnaire; BCQT FUNCT, functional status score; BCQT SYMPT, andsymptom severity score; BOLD, blood-oxygen-level-dependent; CTS, carpal tunnel syndrome; CTSAQ, carpal tunnel syndrome assessment questionnaire; DASH, Disabilities of the Arm Shoulder and Hand questionnaire; EMG, electromyography; FSS, Functional Status Scale; FUNCT, functional status; SSS, Symptom Severity Scale; SYMPT, symptom severity; VAS, Visual Analog Scale.

Note: (-), not available.

periods of time after acupuncture, registering benefits up to 12 weeks later.

From the methodological point of view, over $50 \%$ of the studies showed improvements that were proven with electrophysiology (- Table 3).25,26,29-37,39,40,42 Hadianfard et al (-Table 3), ${ }^{33}$ compared treatment with acupuncture and another with ibuprofen, obtaining a decrease of DSL (distal sensory latency) in the acupuncture group, whereas
DML (distal motor latency) significantly decreased in both groups. Similarly, Yang et al (-Table 3$)^{40}$ also compared acupuncture treatment with treatment using prednisone and in the group with acupuncture, a decrease in distal motor latency was obtained. Occasionally, electrophysiological studies of nerve conduction were combined with other imaging studies, for example the study by Napadow et al. (-Table 3) $)^{25,42}$ combined electrophysiological methods 
22 Acupuncture and electroacupuncture in the treatment of carpal tunnel syndrome Badia, Santafé

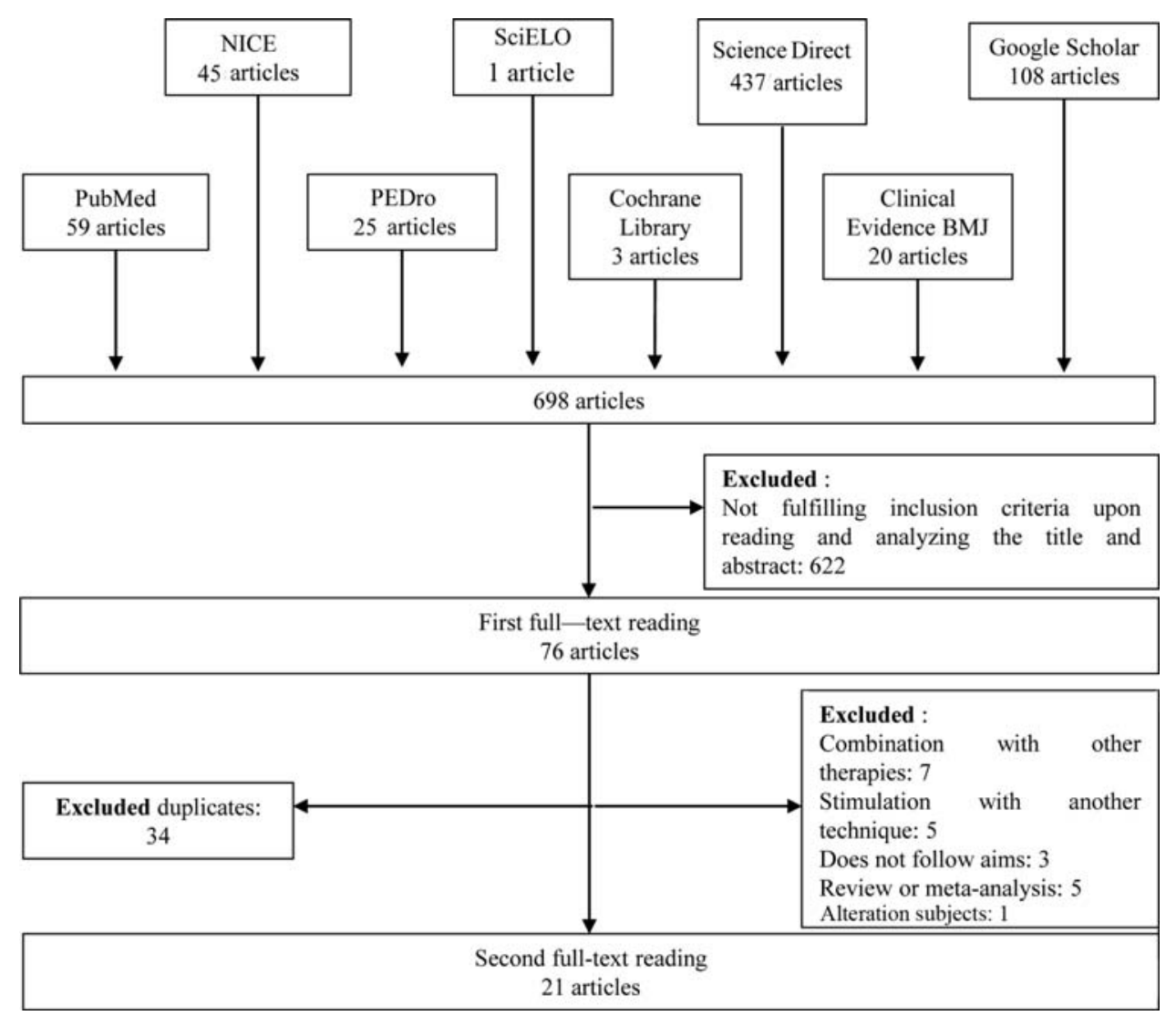

Fig. 1 Study selection process. This figure represents the study selection process, including the selection criteria and reasons for exclusion.

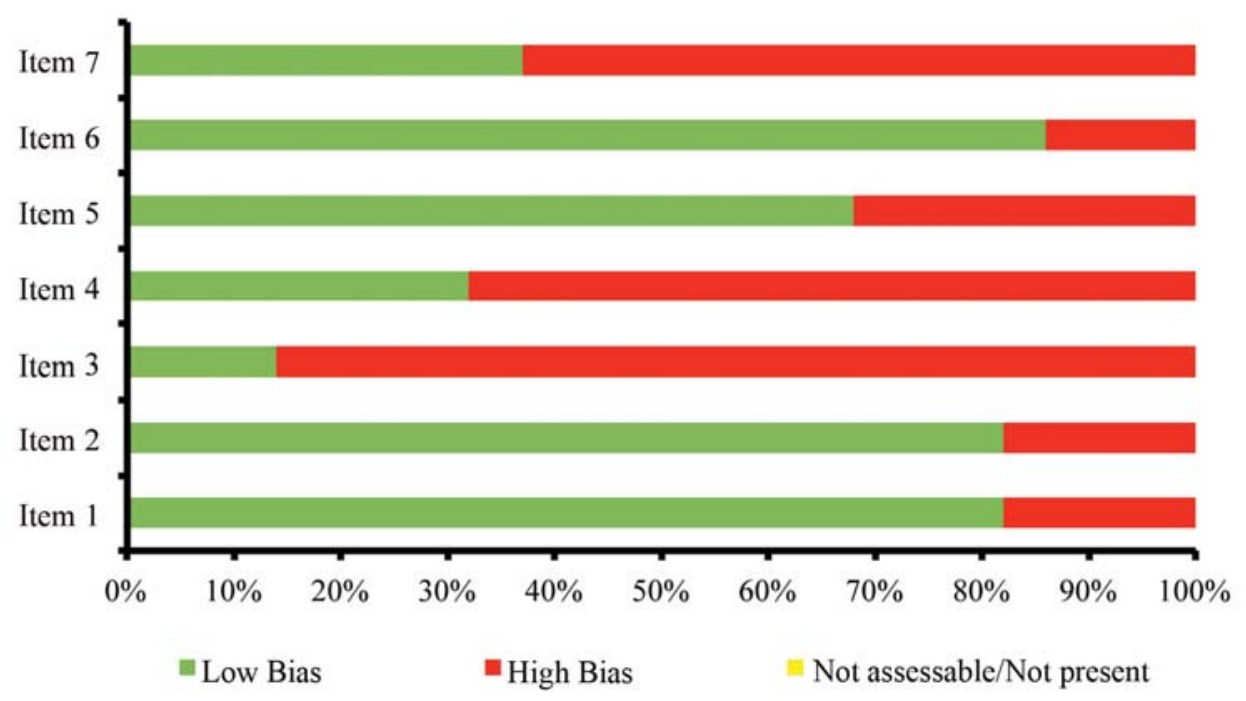

Fig. 2 Graph of risk of bias. Review of the arguments of the authors of the studies included in this systematic review on each item of risk of bias, presented as percentages. Item 1: Generation of the random sequence. Item 2: Concealed allocation. Item 3: Type of blinding of participants and researchers. Item 4: Type of blinding of evaluators. Item 5: Follow-up and exclusions. Item 6: Selective report of results. Item 7: other biases.

(nerve conduction) with functional magnetic resonance, obtaining improved neruophysiological results, both peripheral as well as cerebral after treatment with acupuncture.

Over $25 \%$ of the articles included in this review performed a cerebral assessment using functional magnetic resonance, finding changes which underline the interaction of the effect of acupuncture and electroacupuncture in the improvement of symptoms of patients with CTS (- Table 3). ${ }^{25,32,34,36,41,42}$ In addition, most of these studies also described differences regarding the group of real-simulated acupuncture, localdistal points, symptomatic-asymptomatic side, as well as changes in control subjects at the level of the brain (-Table 3). ${ }^{25,32,34,36,41,42}$ For example, Maeda et al $(- \text { Table 3 })^{32,34}$ performed a functional magnetic resonance 
during the intervention, showing that local electroacupuncture produced an activation of brain areas related with pain modulation, both directly and indirectly, and, however, simulated electroacupuncture did not show any response. ${ }^{32}$

\section{Discussion}

Most articles gathered in this review reveal favorable changes in response to acupuncture and electroacupuncture in CTS. Several studies report that the changes experienced by subjects via the application of acupuncture and elecroacupuncture are maintained during long periods of time after receiving acupuncture.

The maintained improvement of symptoms after real acupuncture found in the present systematic review is in line with the results of previous clinical trials ${ }^{43}$ that relate this effect with the plasticity of the primary somatosensory cortex (S1).

Moreover, the reduction of the symptoms of CTS has been found to persist during months after the cessation of therapy with acupuncture. ${ }^{39}$ These improvements are shown in studies measuring the latency of nerve conduction and cerebral neuroplasticity. It is known that intraneural blood flow is controlled by the sympathetic system; ${ }^{44}$ therefore, it has been proposed that acupuncture may be able to modulate the blood flow of the vasa nervorum of the median nerve via antidromic vasodilation after stimulation of the dorsal spinal roots. Furthermore, using neuroimaging techniques, the S1 has been shown to be a part of the cerebral regions that regulate the outflow of the sympathetic system, ${ }^{45}$ providing feedback to the process. A recent study in patients with chronic pain found an increased connectivity of the S1 and the cortex of the anterior/middle insula that was associated with reduced cardiovagal modulation. ${ }^{46}$ On the peripheral level, this vascular effect could be mediated by the calcitonin gene-related peptide (CGRP). ${ }^{47,48}$ Ultrasound has been used to explore the vascularization of the median nerve trapped in the CTS, ${ }^{49,50}$ observing hypervascularization. This particular vascular situation has been interpreted as a compensatory response to ischemia within the tunnel. This compensation can be due to the decrease in the peripheral afferent, which triggers an increased central processing; therefore, the brain tries to compensate the slower signaling in the periphery by amplifying the signal in regions of somatosensory cerebral processing. A greater activation of the S1 cortex has been described and visualized using functional magnetic resonance ${ }^{51}$ or contralateral electrophysiological amplification ${ }^{52}$ after stimulation of the side affected by CTS, which confirms this hypothesis. In addition, it is known that the activity of the S1 cortex reflects discriminatory sensory information, such as the intensity of the sensation. ${ }^{53,54}$

In several of the assessed studies simulated acupuncture was performed as a placebo in the control group. This indeed is a controversial subject. A previous systematic review affirmed that the evidence of the benefits of acupuncture in the treatment of CTS was unsatisfactory due to the poor methodological quality of the study. ${ }^{55}$ In other words, simulated procedures are not physiologically inert. ${ }^{56,57}$ Indeed, simulated acupuncture has been observed to reduce aversive symptoms more easily than a placebo pill. ${ }^{58}$ Interestingly, analgesia can be obtained with both real and simulated electroacupuncture. The brain mechanisms that support this analgesia can differ substantially. One study by Maeda et $\mathrm{al}^{36}$ for example, described that the brain response in the combined-acupuncture group was more intense than that of the simulatedacupuncture group. The authors described an activity in specific brain regions in response to combined electroacupuncture that may be related to the reduction of pain. One study $^{59}$ also found that this cerebral response is also proposed as an objective marker to discriminate simulated acupuncture from real acupuncture in a more reliable manner than the subjective pain reports made by the patients.

The physiological mechanism of the action of electroacupuncture on CTS pain has also been proposed to occur via the central nervous system. ${ }^{60,61}$ Several studies ${ }^{62,63}$ demonstrate that electroacupuncture induces a large cerebral response in healthy adults. The study by Maeda et $\mathrm{al}^{36}$ demonstrated that electroacupuncture was able to deactivate brain areas of the network in limbic mode in patients with CTS and in healthy subjects on a subthreshold level. Thus, this study by Maeda et $\mathrm{al}^{36}$ differs from previous publications on this subject, possibly because different intensities were used, activation thresholds.

The reduction of pain after real combined electroacupuncture has been related with the activation of the supplementary motor area (SMA). The SMA is a cortical region that modulates the communication between the somatosensory and motor systems, and it has been found to be activated by painful stimulation, as seen on functional magnetic resonance, ${ }^{64}$ and it also contributes to pain control. ${ }^{65}$ A greater activation after combined electroacupuncture can reflect a greater transfer of somatosensory entrances induced by electroacupuncture to the motor system, ${ }^{66}$ promoting a more normalized sensorimotor communication, compared with the sporadic input of diffuse paresthesia. Therefore, electroacupuncture, either local or distal, can also reduce pain by providing a regulated somatosensory entrance to the brain. Therefore, studies ${ }^{66,67}$ involving magnetic resonance have demonstrated that treatment with acupuncture can alter the brain activity and regulate the activity of the limbic system in patients with CTS.

\section{Conclusions}

The studies featured in the present systematic review have a medium to high level of evidence, with a neutral to low risk of bias, which, together, largely validate the present work. Most studies evaluated nerve conduction and functional magnetic resonance imaging, demonstrating beneficial effects of acupuncture and electroacupuncture in the evolution of CTS. Thus, acupuncture and electroacupuncture are treatment options for CTS that may provide clinical and neurophysiological improvements (peripheral and cerebral) that may be superior to those obtained through treatment merely based on the use of nocturnal splints and nonsteroidal anti-inflammatory drugs (NSAIDs). 


\section{Conflict of Interests}

The authors have no conflict interests to declare.

\section{References}

1 Alfonso C, Jann S, Massa R, Torreggiani A. Diagnosis, treatment and follow-up of the carpal tunnel syndrome: a review. Neurol Sci 2010;31(03):243-252

2 Stevens JC; American Association of Electrodiagnostic Medicine. AAEM minimonograph \#26: the electrodiagnosis of carpal tunnel syndrome. Muscle Nerve 1997;20(12):1477-1486

3 Aroori S, Spence RA. Carpal tunnel syndrome. Ulster Med J 2008; 77(01):6-17

4 Jablecki CK, Andary MT, So YT, Wilkins DE, Williams FH; AAEM Quality Assurance Committee. Literature review of the usefulness of nerve conduction studies and electromyography for the evaluation of patients with carpal tunnel syndrome. Muscle Nerve 1993;16(12):1392-1414

5 MacDermid JC, Doherty T. Clinical and electrodiagnostic testing of carpal tunnel syndrome: a narrative review. J Orthop Sports Phys Ther 2004;34(10):565-588

6 Dorwart BB. Carpal tunnel syndrome: a review. Semin Arthritis Rheum 1984;14(02):134-140

7 Viikari-Juntura E, Silverstein B. Role of physical load factors in carpal tunnel syndrome. Scand J Work Environ Health 1999;25 (03):163-185

8 Chammas M. Carpal tunnel syndrome. Chir Main 2014;33(02):75-94

9 Millesi H, Zöch G, Rath T. The gliding apparatus of peripheral nerve and its clinical significance. Ann Chir Main Memb Super 1990;9(02):87-97

10 Lundborg G. Intraneural microcirculation. Orthop Clin North Am 1988;19(01):1-12

11 Ettema AM, Amadio PC, Zhao C, Wold LE, An KN. A histological and immunohistochemical study of the subsynovial connective tissue in idiopathic carpal tunnel syndrome. J Bone Joint Surg Am 2004; 86(07):1458-1466

12 Lundborg G. Nerve entrapment. In: Lundborg G, editor. Nerve injury and repair. Philadelphia (PA): Churchill Livingstone; 1988: 102-148

13 Page MJ, Massy-Westropp N, O'Connor D, Pitt V. Splinting for carpal tunnel syndrome. Cochrane Database Syst Rev 2012;7(07): CD010003

14 Marshall S, Tardif G, Ashworth N. Local corticosteroid injection for carpal tunnel syndrome. Cochrane Database Syst Rev 2007;2(02): CD001554

15 Boyer MI. Corticosteroid injection for carpal tunnel syndrome. J Hand Surg Am 2008;33(08):1414-1416

16 Gong HS, Baek GH, Oh JH, Lee YH, Jeon SH, Chung MS. Factors affecting willingness to undergo carpal tunnel release. J Bone Joint Surg Am 2009;91(09):2130-2136

17 Leyva Glez M, Palomina Carmenate E, Barrios Hdez J, Cruz Font J, Romero Hdez L. Acupuntura del Microsistema Su Jok y quiropraxia en el Síndrome del Túnel Carpiano. Correo Científico Méd Holguín 2011;15(01):

18 Lao L, Zhang G, Wei F, Berman BM, Ren K. Electro-acupuncture attenuates behavioral hyperalgesia and selectively reduces spinal Fos protein expression in rats with persistent inflammation. J Pain $2001 ; 2(02): 111-117$

19 Lao L, Zhang RX, Zhang G, Wang X, Berman BM, Ren K. A parametric study of electroacupuncture on persistent hyperalgesia and Fos protein expression in rats. Brain Res 2004;1020(1-2):18-29

20 Li A, Zhang RX, Wang Y, et al. Corticosterone mediates electroacupuncture-produced anti-edema in a rat model of inflammation. BMC Complement Altern Med 2007;7:27

21 Zhang RX, Lao L, Wang X, et al. Electroacupuncture attenuates inflammation in a rat model. J Altern Complement Med 2005;11 (01):135-142
22 Zhang RX, Lao L, Wang L, Liu B, Wang X, Ren K, Berman BM. Involvement of opioid receptors in electroacupuncture-produced anti-hyperalgesia in rats with peripheral inflammation. Brain Res 2004;1020(1-2):12-17

23 Schulman RA, Liem B, Moroz A. Treatment of carpal tunnel syndrome with medical acupuncture. Med Acupunct 2008;20 (03):163-167

24 Shokunbi GO. Acupuncture and Ergonomic interventions in the management of carpal tunnel syndrome among industrial workers-Case studies. Nigerian J Med Rehabil 2014;17(01):

25 Napadow V, Liu J, Ryan A, et al. Effect of Acupuncture on Carpal Tunnel Syndrome with fMRI Assessment of Cortical Somatotopy. Int Soc Magn Resonance Med 2004;11(01):11-23

26 Zailaa A. Magnetic Resonance Imaging Evaluation of Acupuncture Effects on Carpal Tunnel Syndrome. 2010

27 Ding Q Shen F. Effects of acupuncture and moxibustion of Yangchi point on carpal tunnel syndrome. Int J Traditional Chin Med 2013; 2:117-119

28 Wong CHL, Wu XY, Wong W. Is adding electroacupuncture on top of nocturnal splinting an alternative treatment option for carpal tunnel syndrome patients? AIMED 2016;3(01):31-32

29 Dimitrova A, Murchison C, Oken B. Local effects of acupuncture on the median and ulnar nerves in patients with carpal tunnel syndrome: a pilot mechanistic study protocol. Trials 2019;20(01):8

30 Chen L, Xue L, Li S, Kang T, Chen H, Hou C. [Clinical research on mild and moderate carpal tunnel syndrome treated with contralateral needling technique at distal acupoints and acupuncture at local acupoints]. Zhongguo Zhenjiu 2017;37(05):479-482

31 Ural FG, Öztürk GT. The Acupuncture Effect on Median Nerve Morphology in Patients with Carpal Tunnel Syndrome: An Ultrasonographic Study. Evid Based Complement Alternat Med 2017; 2017:7420648

32 Maeda Y, Kim H, Kettner N, et al. Rewiring the primary somatosensory cortex in carpal tunnel syndrome with acupuncture. Brain 2017;140(04):914-927

33 Hadianfard M, Bazrafshan E, Momeninejad H, Jahani N. Efficacies of Acupuncture and Anti-inflammatory Treatment for Carpal Tunnel Syndrome. J Acupunct Meridian Stud 2015;8(05): 229-235

34 Maeda Y, Kettner N, Lee J, et al. Acupuncture Evoked Response in Contralateral Somatosensory Cortex Reflects Peripheral Nerve Pathology of Carpal Tunnel Syndrome. Med Acupunct 2013a25 (04):275-284

35 Ho CY, Lin HC, Lee YC, et al. Clinical effectiveness of acupuncture for carpal tunnel syndrome. Am J Chin Med 2014;42(02):303-314

36 Maeda Y, Kettner N, Lee J, et al. Acupuncture-evoked response in somatosensory and prefrontal cortices predicts immediate pain reduction in carpal tunnel syndrome. Evid Based Complement Alternat Med 2013b2013:795906

37 Khosrawi S, Moghtaderi A, Haghighat S. Acupuncture in treatment of carpal tunnel syndrome: A randomized controlled trial study. J Res Med Sci 2012;17(01):1-7

38 Kumnerddee W, Kaewtong A. Efficacy of acupuncture versus night splinting for carpal tunnel syndrome: a randomized clinical trial. J Med Assoc Thai 2010;93(12):1463-1469

39 Yang CP, Wang NH, Li TC, et al. A randomized clinical trial of acupuncture versus oral steroids for carpal tunnel syndrome: a long-term follow-up. J Pain 2011;12(02):272-279

40 Yang CP, Hsieh CL, Wang NH, et al. Acupuncture in patients with carpal tunnel syndrome: A randomized controlled trial. Clin J Pain 2009;25(04):327-333

41 Napadow V, Kettner N, Liu J, et al. Hypothalamus and amygdala response to acupuncture stimuli in Carpal Tunnel Syndrome. Pain 2007a130(03):254-266

42 Napadow V, Liu J, Li M, et al. Somatosensory cortical plasticity in carpal tunnel syndrome treated by acupuncture. Hum Brain Mapp 2007b28(03):159-171 
43 Yao E, Gerritz PK, Henricson E, et al. Randomized controlled trial comparing acupuncture with placebo acupuncture for the treatment of carpal tunnel syndrome. PM R 2012;4(05):367-373

44 Beissner F, Meissner K, Bär KJ, Napadow V. The autonomic brain: an activation likelihood estimation meta-analysis for central processing of autonomic function. J Neurosci 2013;33(25):10503-10511

$45 \mathrm{Kim}$ J, Loggia ML, Cahalan CM, et al. The somatosensory link in fibromyalgia: functional connectivity of the primary somatosensory cortex is altered by sustained pain and is associated with clinical/autonomic dysfunction. Arthritis Rheumatol 2015;67 (05):1395-1405

46 Padua L, Coraci D, Erra C, Pazzaglia C, Paolasso I, Loreti C, Caliandro P, Hobson-Webb LD. Carpal tunnel syndrome: clinical features, diagnosis, and management. Lancet Neurol 2016;15:1273-1284

47 Sato A, Sato Y, Uchida S. Blood flow in the sciatic nerve is regulated by vasoconstrictive and vasodilative nerve fibers originating from the ventral and dorsal roots of the spinal nerves. Neurosci Res 1994;21(02):125-133

48 Ooi CC, Wong SK, Tan AB, et al. Diagnostic criteria of carpal tunnel syndrome using high-resolution ultrasonography: correlation with nerve conduction studies. Skeletal Radiol 2014;43(10):1387-1394

49 Ghasemi-Esfe AR, Khalilzadeh O, Mazloumi M, et al. Combination of high-resolution and color Doppler ultrasound in diagnosis of carpal tunnel syndrome. Acta Radiol 2011;52(02):191-197

50 Napadow V, Dhond R, Kennedy D, Hui KK, Makris N. Automated brainstem co-registration (ABC) for MRI. Neuroimage 2006;32 (03):1113-1119

51 Tecchio F, Padua L, Aprile I, Rossini PM. Carpal tunnel syndrome modifies sensory hand cortical somatotopy: a MEG study. Hum Brain Mapp 2002;17(01):28-36

52 Coghill RC, Sang CN, Maisog JM, Iadarola MJ. Pain intensity processing within the human brain: a bilateral, distributed mechanism. J Neurophysiol 1999;82(04):1934-1943

53 Derbyshire SW, Jones AK, Gyulai F, Clark S, Townsend D, Firestone LL. Pain processing during three levels of noxious stimulation produces differential patterns of central activity. Pain 1997;73 (03):431-445

54 Sim H, Shin BC, Lee MS, Jung A, Lee H, Ernst E. Acupuncture for carpal tunnel syndrome: a systematic review of randomized controlled trials. J Pain 2011;12(03):307-314
55 Lund I, Lundeberg T. Are minimal, superficial or sham acupuncture procedures acceptable as inert placebo controls? Acupunct Med 2006;24(01):13-15

56 Linde K, Niemann K, Schneider A, Meissner K. How large are the nonspecific effects of acupuncture? A meta-analysis of randomized controlled trials. BMC Med 2010;8:75

57 Kaptchuk TJ, Stason WB, Davis RB, et al. Sham device v inert pill: randomised controlled trial of two placebo treatments. BMJ 2006; 332(7538):391-397

58 Harris RE, Zubieta JK, Scott DJ, Napadow V, Gracely RH, Clauw DJ. Traditional Chinese acupuncture and placebo (sham) acupuncture are differentiated by their effects on mu-opioid receptors (MORs). Neuroimage 2009;47(03):1077-1085

59 Napadow V, Lee J, Kim J, et al. Brain correlates of phasic autonomic response to acupuncture stimulation: an event-related fMRI study. Hum Brain Mapp 2013;34(10):2592-2606

60 Claunch JD, Chan ST, Nixon EE, et al. Commonality and specificity of acupuncture action at three acupoints as evidenced by FMRI. Am J Chin Med 2012;40(04):695-712

61 Yan B, Li K, Xu J, et al. Acupoint-specific fMRI patterns in human brain. Neurosci Lett 2005;383(03):236-240

62 Zhang WT, Jin Z, Luo F, Zhang L, Zeng YW, Han JS. Evidence from brain imaging with fMRI supporting functional specificity of acupoints in humans. Neurosci Lett 2004;354(01):50-53

63 Hui KK, Liu J, Makris N, et al. Acupuncture modulates the limbic system and subcortical gray structures of the human brain: evidence from fMRI studies in normal subjects. Hum Brain Mapp 2000;9(01):13-25

64 Huang W, Pach D, Napadow V, et al. Characterizing acupuncture stimuli using brain imaging with FMRI-a systematic review and meta-analysis of the literature. PLoS One 2012;7(04):e32960

65 Peyron R, Laurent B, García-Larrea L. Functional imaging of brain responses to pain. A review and meta-analysis (2000). Neurophysiol Clin 2000;30(05):263-288

66 Shinoura N, Suzuki Y, Yamada R, Kodama T, Takahashi M, Yagi K. Fibers connecting the primary motor and sensory areas play a role in grasp stability of the hand. Neuroimage 2005;25(03):936-941

67 Asghar AU, Green G, Lythgoe MF, Lewith G, MacPherson H. Acupuncture needling sensation: the neural correlates of deqi using fMRI. Brain Res 2010;1315:111-118 